\title{
OCCURRENCE OF ATHIORHODACEAE IN WOODLAND, SWAMP, AND POND SOILS ${ }^{1}$
}

\author{
Douglas C. Pratt and Eville Gorham \\ Department of Botany, University of Minnesota, Minneapolis, Minnesota
}

(MS received July 17, 1969; accepted November 6, 1969)

\begin{abstract}
Tests (by enrichment culture) for nonsulfur purple photosynthetic bacteria in surface soils showed them in all of three sediment cores sampled in a shallow pond and in all of six peats from nearby swamp hollows beneath cedar and tamarack. They also occurred in two of three peats from swamp flats and three of five peats from swamp hummocks. For woodland and grassland surface soils, proportions were three out of seven and five out of nine sites respectively. For the total number of tubes inoculated at varying dilutions from each of these sites, the following proportions of positives were recorded: uppermost lake sediments $92 \%$, swamp hollows $67 \%$, swamp flats $38 \%$, swamp hummocks $20 \%$, woodlands $14 \%$, grasslands $8 \%$.
\end{abstract}

In a study of chlorophyll derivatives in woodland, swamp and pond soils (Gorham and Sanger 1964), absorption spectra of acetone extracts from a few peats collected in swamp hollows exhibited a minor peak at about $750 \mathrm{~nm}$ (Fig. 1). Such a peak suggested the presence of bacteriopheophytin, a breakdown product of bacteriochlorophyll, which in turn indicated the presence of photosynthetic bacteria in these samples. Although the photosynthetic bacteria have been the subject of much study (Pfennig 1967) their ecology has not received proportionate attention, and the present investigation was undertaken to examine the occurrence of nonsulfur, purple photosynthetic bacteria (Athiorhodaceae) along a soil-moisture gradient from saturated pond soils and peats in swamp hollows through wet peats in swamp flats and drier peats in swamp hummocks to dry upland soils in both woodland and grassland.

\section{Sampling Methods}

Surface samples were collected during the summer of 1968 in soils from a variety of habitats in the Cedar Creek Natural History Area north of Minneapolis. Upland and swamp samples were taken approximately within the top $2 \mathrm{~cm}$, but lake muds were taken up to a depth of about $20 \mathrm{~cm}$ with a Jenkin core sampler (Mortimer 1941-42; Fig. 22). Most samples were collected in old fields, mixed woodlands, and cedar and tamarack swamps in the vicinity of Cedar Bog Lake, and samples were also taken in the lake itself, which is actually a small pond a little over $1 \mathrm{~m}$ deep. More detailed descriptions of the area are given by Lindeman (1941), Conway (1949), and Gorham and Sanger (1964). The last-named authors provided data on soil $\mathrm{pH}$, water and organic con-

${ }^{1}$ Contribution No. 82 from the Limnological Research Center, University of Minnesota.

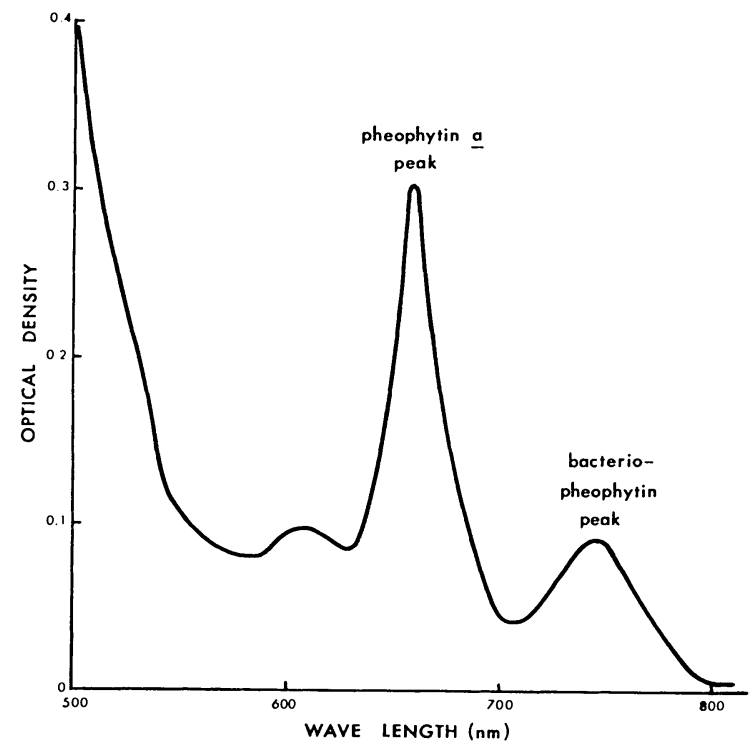

FIG. 1. Absorption spectrum for acetone extract of peat from swamp hollow.

tent, and also (Gorham and Sanger 1967) analyzed the caloric values of soil organic matter in the same habitats.

\section{Methods For ENRICHING AND IDENTIFying Photosynthetic Bacteria}

To test for the presence of non-sulfur, purple photosynthetic bacteria, samples were inoculated into screw-capped culture tubes of $25 \mathrm{ml}$ volume, containing an enrichment medium similar to that described by Skerman (1959). The final medium typically contained the following amounts of material per liter of distilled water: $1.0 \mathrm{~g} \mathrm{NH}_{4} \mathrm{Cl}$, $1.96 \mathrm{~g} \mathrm{KH}_{2} \mathrm{PO}_{4}, 3.33 \mathrm{~g} \mathrm{~K}_{2} \mathrm{HPO}_{4} \cdot 3 \mathrm{H}_{2} \mathrm{O}, 0.2 \mathrm{~g}$ $\mathrm{MgCl}_{2}, 2.0 \mathrm{~g} \mathrm{NaCl}, 0.1 \mathrm{~g}$ Difco yeast extract, $5.0 \mathrm{~g}$ $\mathrm{NaHCO}_{3}, 2.0 \mathrm{~g} \mathrm{D}-\mathrm{L}$ alanine. In one experiment 
$6.0 \mathrm{~g} /$ liter D-L alanine was used with no apparent effect on growth rates. For lake samples 2.0 $\mathrm{g} /$ liter bactopeptone was used in place of alanine because of its greater effectiveness in suppressing algal growth. The use of chloride salts as opposed to sulfates is in accordance with the suggestion of van Niel (1944), who found that this practice precluded the growth of sulfate-reducing bacteria and concomitant development of purple sulfur bacteria (Thiorhodaceae). The medium minus the sodium bicarbonate was sterilized in an autoclave for $20 \mathrm{~min}$ at $120^{\circ} \mathrm{C}$. A solution of sodium bicarbonate was sterilized by filtration and added to the otherwise complete medium after inoculation.

Inoculations in the field were made by swabbing a soil surface to be tested with a sterile cotton Q-tip. The end of the Q-tip was then broken off and placed in a screw-cap tube containing sterile enrichment medium. Controls were inoculated in the same manner omitting the surface swabbing step. (Before making inoculations or collections at a given site, investigators swabbed their hands thoroughly with sterile cotton doused liberally with $95 \%$ ethyl alcohol.) Upon returning to the laboratory bicarbonate was added to all tubes. The tubes were then filled to the top with sterile medium to displace the remaining air.

Surface soil samples were collected at each site and sealed in polyethylene bags. These samples were kept in shaded, cool locations until they could be returned to the laboratory for additional testing. On especially hot days samples were stored on ice in a polystyrene box. The Cedar Creek Natural History Area is about $50-\mathrm{km}$ from the Minneapolis Campus and in no case did more than 3 or $4 \mathrm{hr}$ transpire between the time of collection and the time when the samples reached the laboratory for processing.

In the laboratory, material from each plastic bag was transferred aseptically to a sterile culture tube. Twenty $\mathrm{ml}$ of sterile enrichment medium was added, the tube shaken and allowed to stand for several minutes. Material from the same site was sterilized in an autoclave for $20 \mathrm{~min}$ and sampled in similar fashion to provide a check on procedures. No growth occurred in any of the field or laboratory controls. Subsamples at varying dilutions over a range of almost three orders of magnitude were removed from each inoculating tube with either a sterile wire loop or pipette and transferred to enrichment tubes containing sterile medium. Bicarbonate was added and the enrichment tubes were filled to the brim with sterile medium, tightly capped, and placed in incubation racks.
Tubes were incubated at an average distance of $23 \mathrm{~cm}$ from light banks containing $40 \mathrm{~W}$ tungsten bulbs. The temperature was $27 \pm 3{ }^{\circ} \mathrm{C}$.

A comparison of the amount of insoluble organic material in each inoculating tube from a given site was obtained by centrifuging all particulate material remaining in the inoculating tube, washing it with distilled water, and drying it to constant weight at $90^{\circ} \mathrm{C}$. After ashing the material in a muffle furnace for $4 \mathrm{hr}$ at $500^{\circ} \mathrm{C}$, the difference in the weights of dried and ashed material was reported as organic content. Since these surface soils were noncalcareous and sandy, with almost no clay, and especially since all but the grassland samples were highly organic, ignition loss provided a reasonable measure of soil organic content.

The proportion of positives recorded did not depend upon the amount of organic matter in the inoculation tube. In fact, the highest proportion of positives was observed in the lake muds, which averaged the smallest amount of organic inoculum. The degree of dilution of the initial inoculum also had rather little effect, since dilutions of between two and three orders of magnitude only reduced the proportion of positives by about one-third. In presenting results, therefore, all dilutions are included together in the tabulations.

A pink, orange, or straw-colored pigmentation in the culture tubes was associated with the development of photosynthetic bacteria. After approximately 2 weeks of incubation, growth from an enrichment culture was sedimented in a clinical centrifuge. Following procedures similar to those of Cohen-Bazire, Sistrom and Stanier (1957), the sedimented material was extracted with a 7:2 mixture of acetone and methanol. The absorption spectrum of the extract was measured in a Cary model 15 spectrophotometer. Prominent and distinctive bacteriochlorophyll absorption peaks at approximately $770 \mathrm{~nm}$ and $360 \mathrm{~nm}$ were considered as confirmatory evidence of the presence of photosynthetic bacteria (Kihara and Frenkel 1963). Several intermediate peaks, of more varied positions and prominence, were also observed. Presumably several of these peaks were due to differing kinds and amounts of carotenoids in the various species present.

Gram stains and observations with the light microscope were also performed routinely on all cultures. Although both genera of Athiorhodaceae were observed, the rod-shaped or spherical Rhodopseudomonas were far more abundant than the spiral-shaped Rhodospirillum. Since the relative abundance of the two genera could be influenced by enrichment techniques, this is not necessarily an indication of a greater natural prevalence of Rhodopseudomonas. 
TABLE 1. Summary of data on the occurrence of Athiorhodaceae along a gradient of soil moisture

\begin{tabular}{|c|c|c|c|c|c|c|c|}
\hline Type of site & $\begin{array}{c}\text { Average soil } \\
\text { organic } \\
\text { matter } \\
\text { (mg/inoc. } \\
\text { tube) }\end{array}$ & $\begin{array}{c}\text { Sites } \\
\text { positive/ } \\
\text { total }\end{array}$ & $\begin{array}{c}\text { Percent } \\
\text { positive } \\
\text { sites }\end{array}$ & $\begin{array}{l}\text { Tubes }^{\mathrm{a}} \\
\text { positive/ } \\
\text { total }\end{array}$ & $\begin{array}{c}\text { Percent } \\
\text { positive } \\
\text { tubes }\end{array}$ & $\begin{array}{c}\text { Field } \\
\text { samples } \\
\text { positive/ } \\
\text { total }\end{array}$ & $\begin{array}{l}\text { Tubes } \\
\text { with } \\
\text { algae }\end{array}$ \\
\hline $\begin{array}{l}\text { Lake sediment } \\
\text { top } \\
\text { middle } \\
\text { bottom }\end{array}$ & $\begin{array}{l}121 \\
128 \\
160\end{array}$ & $\begin{array}{l}3 / 3 \\
3 / 3 \\
3 / 3\end{array}$ & $\left.\begin{array}{l}100 \\
100 \\
100\end{array}\right\} 100$ & $\begin{array}{l}33 / 36 \\
30 / 36 \\
28 / 36\end{array}$ & $\left.\begin{array}{l}92 \\
83 \\
78\end{array}\right\} 84$ & & $\begin{array}{r}13 / 36 \\
3 / 36 \\
0 / 36\end{array}$ \\
\hline $\begin{array}{l}\text { Swamp peat } \\
\text { hollow } \\
\text { flat } \\
\text { hummock }\end{array}$ & $\begin{array}{l}334 \\
162 \\
269\end{array}$ & $\begin{array}{l}6 / 6 \\
2 / 3 \\
3 / 5\end{array}$ & $\left.\begin{array}{r}100 \\
67 \\
60\end{array}\right\} 79$ & $\begin{array}{l}44 / 66 \\
13 / 34 \\
11 / 54\end{array}$ & $\left.\begin{array}{l}67 \\
38 \\
20\end{array}\right\} 44$ & $\begin{array}{l}4 / 14 \\
2 / 6 \\
0 / 4\end{array}$ & \\
\hline $\begin{array}{l}\text { Woodland humus } \\
\text { layer } \\
\text { near swamp, south } \\
\text { near swamp, north } \\
\text { far from swamp }\end{array}$ & $\begin{array}{l}240 \\
343 \\
312\end{array}$ & $\begin{array}{l}2 / 2 \\
1 / 3 \\
0 / 2\end{array}$ & $\left.\begin{array}{r}100 \\
33 \\
0\end{array}\right\} 43$ & $\begin{array}{r}10 / 20 \\
1 / 36 \\
0 / 24\end{array}$ & $\left.\begin{array}{r}50 \\
3 \\
0\end{array}\right\} 14$ & $\begin{array}{l}0 / 4 \\
0 / 6 \\
0 / 4\end{array}$ & \\
\hline Grassland soil & 573 & $5 / 9$ & 56 & $8 / 100$ & 8 & $0 / 18$ & \\
\hline
\end{tabular}

Laboratory inoculations only.

\section{Results}

Tests for the presence of photosynthetic bacteria in sediments from Cedar Bog Lake are summarized in Table 1, both for the sites investigated and for the total number of tubes inoculated at these sites. Photosynthetic bacteria were found throughout the cores from the Jenkin sampler, in all sites and in more than three-quarters of the tubes inoculated. As mentioned earlier, a modified medium containing peptone in place of alanine was used in the studies of lake sediments. Preliminary experiments with lake samples and alanine medium had shown that algae developed very quickly in this medium, suppressing the growth of photosynthetic bacteria. In peptone medium algae also developed, but more slowly, and only after the photosynthetic bacteria were readily apparent. Algae were especially common in tubes inoculated from the top of the core and were never found in tubes inoculated from the bottom. This suggests that the abundance of photosynthetic bacteria at the lower levels could not be explained by mixing or smearing in the core.

Table 1 also gives the results of sampling in the swamps around Cedar Bog Lake. Photosynthetic bacteria were present in the majority of sites tested, and in all of the swamp hollows. Of the total number of tubes inoculated, two-thirds yielded positives in the hollows, as against one-fifth in the drier hummocks. The two driest hummocks gave no positives. Inoculations made in the field with Q-tips were positive less often than those made in the laboratory. Tubes showing growth gener- ally turned turbid after four to seven days of incubation. Within one or two more days noticeable pigmentation could usually be observed. When peptone was substituted for alanine in testing lake samples almost all tubes were turbid within one or two days and pigmentation could only be detected after an additional five to seven days. Apparently the peptone medium supported an initial growth of heterotrophs which were eventually supplanted by photosynthetic organisms.

Three out of seven woodland sites surrounding the lake yielded photosynthetic bacteria (Table 1), but only $14 \%$ of the tubes were positive. Two sites giving the most positive results were on a side of the lake which was relatively open, and near an established path providing easy access to the lake through the swamp. The vicinity of the path is frequently used for research, which may increase transport of bacteria between swamp and upland. In woodland sites sampled on the opposite side of the lake, where access was difficult because of heavy vegetation, results were much more negative.

Five of nine grassland sites in the area bordering the lake and the woods gave evidence of photosynthetic bacteria (Table 1). However, only in one site, where sand was mixed with abundant surface litter, was there more than a single positive tube recorded.

\section{Discussion}

Site types are arranged in Table 1 from top to bottom in order of increasing dryness of site and also distance from Cedar Bog Lake, except that two of the woodland sites were at a different lo- 
cation in the Natural History Area some distance from the lake.

It is clear that Athiorhodaceae were usually present in the pond muds and in the wet swamp hollows, with all sites and two-thirds or more of the tubes giving a positive response. Although these photosynthetic bacteria were still commonly present in the swamp flats and hummocks, their frequency of occurrence declined distinctly. In the upland woods and old fields positives were obtained from about half the sites studied, but only in less than 15 percent of the tubes inoculated.

The foregoing results demonstrate, as expected, that the occurrence of Athiorhodaceae is strongly dependent upon the degree of soil waterlogging. Positives were recorded occasionally from dry woodland and grassland sites, but were common only in wet swamp and pond soils near to or below the water-table. Data of Gorham and Sanger (1964) indicate that soil water content in summer averages $97 \%$ of fresh soil weight for pond muds and $88 \%$ for swamp peats from hollows and flats, as against $59 \%$ for swamp hummock peats and $32 \%$ for woodland humus layers.

Although we have not attempted to measure the activity of the photosynthetic bacteria in the various sites, it seems reasonable to conclude that they are most active in those sites where they occur with greatest frequency, and in which the anaerobic and microaerophilous conditions most suitable to their metabolism are prevalent.

\section{ACKNOWLEDGMENTS}

We are indebted to Miss Rochelle Eastman, Miss Pearl Lam, Miss Bernice Folz and Gregory Pratt for help with sampling and for the laboratory work. Financial assis- tance was provided through the courtesy of $\mathrm{H}$. E. Wright, Jr., from a grant by the Minnesota Resources Commission to the Limnological Research Center of the University of Minnesota. The equipment used was purchased with the aid of several grants to the authors by the $\mathrm{Na}$ tional Science Foundation and by the Graduate School of the University of Minnesota. Finally, it is a pleasure to thank W. H. Marshall, Director of the Cedar Creek Natural History Area, for permission to collect samples.

\section{Literature Cited}

Cohen-Bazire, G., W. R. Sistrom, and R. Y. Stanier. 1957. Kinetic studies of pigment synthesis by nonsulfur purple bacteria. J. Cell. Comp. Physiol. 49: $25-68$.

Conway, V. M. 1949. The bogs of central Minnesota. Ecol. Monogr. 19: 173-206.

Gorham, E., and J. Sanger. 1964. Chlorophyll derivatives in woodland, swamp, and pond soils of Cedar Creek Natural History Area, Minnesota, U.S.A., p. 1-12. In Y. Miyake and T. Koyama [ed.] Recent researches in the fields of hydrosphere, atmosphere and nuclear geochemistry. Maruzen Co., Tokyo.

- 1967. Caloric values of organic matter in woodland, swamp, and lake soils. Ecology 48: 492-494.

Kihara, T., and A. W. Frenkel. 1963. Isolation of bacteriopheophytin-containing particles from Rhodospirillum rubrum, p. 115-119. In $\mathrm{H}$. Gest, A. San Pietro, L. P. Vernon, [ed.] Bacterial photosynthesis. The Antioch Press, Yellow Springs, Ohio.

Lindeman, R. L. 1941. The developmental history of Cedar Creek Bog, Minn. Amer. Midland Naturalist 25: 101-112.

Mortimer, C. H. 1941-42. The exchange of dissolved substances between mud and water in lakes. J. Ecol. 29: 280-329 and 30: 147-201.

Pfennig, N. 1967. Photosynthetic bacteria. Ann. Rev. Microbiol. 21: 285-324.

Skerman, V. B. D. 1959. A guide to the identification of the genera of bacteria, with methods and digests of generic characteristics. Williams \& Wilkins, Baltimore. $217 \mathrm{p}$.

van Niel, C. B. 1944. The culture, general physiology, morphology, and classification of the non-sulfur purple and brown bacteria. Bacteriol. Rev. 8: 1-118. 